\title{
Assessment of Curing Exposures Effect on the Long-term Engineering Properties of Novel Lightweight Aggregate Concrete
}

\author{
Mohammad H. Jannaty ${ }^{1}$ and Dawood Atrushi ${ }^{2}$ \\ ${ }^{1}$ Department Of Civil Engineering, Islamic Azad University, \\ Sanandaj Branch, Iran \\ ${ }^{2}$ Department of Civil Engineering, College of Engineering, University of Duhok, \\ Duhok, Kurdistan Region - F.R. Iraq
}

\begin{abstract}
At present, most of the generated waste expanded polystyrene (EPS) in developed countries are transported to landfill and in some developing and/or less-developed countries such as Iraq are sent to open landscapes; consequently, this inadequate waste disposal can be very dangerous to our health and environment. This study describes engineering properties of sustainable lightweight aggregate concrete (LWAC) incorporating novel aggregates of waste EPS produced by a unique recycling technique of densifying. The new recycling technique significantly improved the segregation resistance of EPS beads in concrete as these beads are ultra-light material. The novel LWA of densified EPS (DEPS) was used as partial natural aggregate replacement in the mixes. Three water/cement $(\mathrm{W} / \mathrm{C})$ ratios were used. Three different types of curing conditions of indoor full water curing, outdoor weathering exposure, and heating exposure were employed during this study to represent different conditions which concrete may be subject to. The engineering properties of concrete investigated were consistency, dry density, compressive strength, and ultrasonic pulse velocity (UPV) for long-term performance of more than one-year age. It was indicated that the properties of concrete were not only primarily influenced by the employed curing conditions but the content of DEPS in the mixtures and additionally the $W / C$ ratio had effect on the properties of concrete. However, adequate engineering properties can be achieved using an appropriate amount of DEPS with proper $\mathrm{W} / \mathrm{C}$ and curing conditions.
\end{abstract}

Index Terms - Compressive strength, Curing conditions, LWAC, Ultrasonic pulse velocity, Weathering Expanded polystyrene.

\section{INTRODUCTION}

Expanded polystyrene (EPS) is mostly used in the packaging industry, but it can be used in the building industry as an insulation material in concrete wall blocks and in other global

ARO-The Scientific Journal of Koya University

Vol. VIII, No.2 (2020), Article ID: ARO.10739, 9 pages

DOI:10.14500/aro.10739

Received: 09 October 2020; Accepted: 24 November 2020

Regular research paper: Published: 08 December 2020

Corresponding author's e-mail: dawood.sulaiman@uod.ac

Copyright (C) 2020 Mohammad H. Jannaty and Dawood Atrushi. This

is an open-access article distributed under the Creative Commons

Attribution License. industrial fields. This is due to the fact that EPS has low thermal conductivity, which makes it a very good insulating material. It has low density and almost zero compressive strength. A large quantity of EPS is disposed of in landfills as waste in developed countries. Unfortunately, in developing and less-developed countries such as Iraq and in particular in Kurdistan Region of Iraq (KRI) this waste are collected, transported, and dumped in open space areas which are dangerous for the environment and public health (Herki and Khatib, 2016; Khatib, Herki and Elkordi, 2019).

According to the literature reported to date (Table I), using unmodified shredded waste EPS directly in concrete or mortar as aggregate can be the most efficient method of utilizing and reusing waste materials from sustainability point of view. However, EPS beads are extremely light with very low densities which can cause segregation in mixes as researchers are still trying to solve this problem. In addition, EPS beads are hydrophobic, which ends in poor bonding to cement paste. Hence, some studies (Table I) have conducted experimental investigations to enhance the engineering properties and to improve segregation resistance using different techniques and materials such as adding some bonding additives such as aqueous epoxy emulsions and aqueous dispersions of polyvinyl propionate, and chemically pre-treated EPS beads. There were other techniques such as adding ultra-fine silica fume (SF) to increase the bonding between EPS beads and cement paste and using superplasticizers to increase the workability of concrete, etc. However, these techniques might not be environmentally friendly and readily available in all countries. In addition, the reusing and recycling of waste materials in developing and less-developed countries are still in its early phases (Miled, 2004; Herki, 2017; Khatib et al., 2013). Using silica stone waste (SSW) is another waste material which can be used as a substitution for cement and contribute to a better bonding and higher mechanical properties such as compressive and tensile strength.

Some previous studies (Table I) reported mechanical and durability performance of concrete containing EPS as fine and/or coarse aggregates. The compressive strength of 
TABLE I

Previous STUdies ON CONCRETE CONTAINING EPS

\begin{tabular}{|c|c|c|c|c|}
\hline \multirow[t]{2}{*}{ References } & \multirow[t]{2}{*}{ Mixture } & \multirow[t]{2}{*}{ Density $\left(\mathrm{kg} / \mathrm{m}^{3}\right)$} & \multicolumn{2}{|c|}{ "Compressive strength (MPa) } \\
\hline & & & 7 days & 28 days \\
\hline Ravindrarajah, Camporeale, and Caraballo (1996) & $\mathrm{EPS}+\mathrm{NA}+\mathrm{C}$ & $1100-1920$ & - & $8.5-37.5$ \\
\hline Sabaa and Ravindrarajah (1997) & $\mathrm{EPS}+\mathrm{NA}+\mathrm{C}$ & $1600-2000$ & - & $8.8-21.3$ \\
\hline Park and Chilsholm (1999) & $\mathrm{EPS}+\mathrm{NA}+\mathrm{C}$ & 820 & 3.2 & 3.8 \\
\hline Babu (2003) & $\mathrm{EPS}+\mathrm{NA}+\mathrm{SF}+\mathrm{C}$ & $1503-1979$ & $7.6-19.8$ & $10.2-21.4$ \\
\hline Chen and Liu (2004) & $\mathrm{EPS}+\mathrm{NA}+\mathrm{SF}+\mathrm{C}$ & $876-1929$ & $7.3-21.1$ & $9.9-25.9$ \\
\hline Miled, 2004 & $\mathrm{EPS}+\mathrm{NA}+\mathrm{C}$ & 1810 & - & $7.6-8.5$ \\
\hline Ganesh Babu and Saradhi Babu (2004) & $\mathrm{EPS}+\mathrm{NA}+\mathrm{FA}+\mathrm{C}$ & $582-1723$ & - & $1.1-12.5$ \\
\hline Ganesh Babu and Wee (2004) & $\mathrm{EPS}+\mathrm{NA}+\mathrm{FA}+\mathrm{C}$ & $582-1723$ & $0.62-5.96$ & $1.1-12.5$ \\
\hline Laukaitis, Žurauskas and Kerien (2005) & $\mathrm{EPS}+\mathrm{C}$ & $149-275$ & $0.1-0.75$ & - \\
\hline Saradhi Babu, Ganesh Babu and Tiong-Huan (2006) & $\mathrm{EPS}+\mathrm{NA}+\mathrm{FA}+\mathrm{SF}+\mathrm{C}$ & $1012-1858$ & $4.0-30.0$ & $5.5-34.0$ \\
\hline Bouvard (2007) & $\mathrm{EPS}+\mathrm{C}$ & $432-961$ & $0.8-11.4$ & - \\
\hline Kan and Demirboğa (2007) & $\mathrm{EPS}+\mathrm{C}$ & $464-1370$ & - & $0.11-8.5$ \\
\hline Chen and Liu (2007) & $\mathrm{EPS}+\mathrm{NA}+\mathrm{SBR}+\mathrm{C}$ & - & - & $11.2-16.3$ \\
\hline Tang, Lo and Nadeem (2008) & $\mathrm{EPS}+\mathrm{NA}+\mathrm{C}$ & $1396-2094$ & $11.7-32.2$ & $13.1-39.3$ \\
\hline Kan and Demirboğa (2009) & $\mathrm{MEPS}+\mathrm{NA}+\mathrm{C}$ & $980-1734$ & $11.8-013.4$ & $12.6-17.6$ \\
\hline Sadrmomtazi (2012) & $\mathrm{EPS}+\mathrm{SF}+\mathrm{RHA}+\mathrm{C}$ & - & - & $6.7-33.0$ \\
\hline Herki (2017) & $\mathrm{SPS}+\mathrm{C}$ & $891-1814$ & $0.5-7.0$ & $1.0-10.0$ \\
\hline Nikbin and Golshekan (2018) & $\mathrm{EPS}+\mathrm{SF}+\mathrm{C}$ & $1611-2312$ & $0.02-0.05$ & $12.4-47.8$ \\
\hline Present study & $\mathrm{DEPS}+\mathrm{NA}+\mathrm{C}$ & $891-1961$ & $1.81-11.26$ & $3.0-16.43$ \\
\hline
\end{tabular}

EPS concretes was found to be directly proportional to the concrete's density. The common conclusion of these studies (Khatib et al., 2019; Nikbin and Golshekan, 2018; Herki et al., 2013) shows that an increase in the amount of EPS beads can lead to a weaker concrete integrity since EPS beads does not provide any compression strength, and this is a big disadvantage of concrete with EPS mixtures. It was also presented that water absorption of concrete by total and capillary action will increase with an increase in EPS replacement level in concrete. This is due to microcracks of shrinkage action in concrete incorporating EPS beads. Although, research on LWAC containing EPS has exaggerated in the past two decades as there are still gaps in the knowledge of the properties and behavior of EPS concrete. One reason is that EPS concrete properties can vary considerably depending on the type of EPS and the technique of waste EPS recycling used, and so any conclusions may only be valid for the specific cases studied indicated in the above-mentioned research sources.

Reviewing the published studies in this line reveals that there is not enough information in the literature on assessment of different curing exposures effect on the long-term (365 days) engineering properties of lightweight aggregate concrete incorporating EPS using this novel technique.

\section{EXPERIMENTAL Plan}

\section{A. Material}

For the present project, the mixed natural sand and gravel aggregates were used in the lab. For economic reasons and in line with materials that normally used in Kurdistan Region for production of concrete blocks (Rostam et al., 2016), the normal aggregate used was low-cost and it was crushed limestone. The size ranges were between 0 and $10 \mathrm{~mm}$ complied with the British

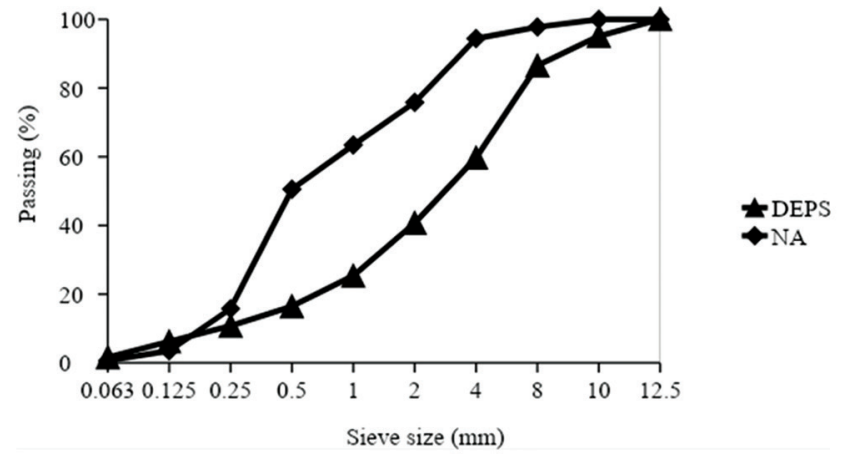

Fig. 1. Particle size distributions of natural and DEPS aggregates

standard requirements. Bulk density, specific gravity (SSD), and water absorption ( $24 \mathrm{~h}$ ) of natural aggregates were $1677 \mathrm{~kg} /$ $\mathrm{m}^{3}, 2.69$, and $1.2 \%$, respectively. The particle size distributions (sieving) details of natural aggregate and the novel aggregate of densified expanded polystyrene (DEPS) complied with BS EN 933-1-2012 are presented in Fig. 1 for geometrical properties of aggregates and determination of particle size distribution. The DEPS aggregate has been made from $80 \%$ crushed waste EPS, $10 \%$ cement, and $10 \%$ red clay powder. The bulk density, SSD, and water absorption ( $24 \mathrm{~h}$ ) of DEPS were $459 \mathrm{~kg} / \mathrm{m}^{3}, 0.7$, and $12 \%$, respectively. It is worth mentioning here that, generally, LWAs have high porosity resulting in higher water absorption (WA) compared with natural aggregates. The cement used was ordinary Portland cement Type I. The chemical composition of cement is given in Table II.

\section{B. Concrete Mixtures}

The mix proportion of 1 (cement): Six (mixed natural sand and gravel aggregates) have been selected for the control mix. The replacement levels of natural aggregates with DEPS beads were $0,30,60$, and $100 \%$ (by volume). The 
TABLE II

Chemical compositions of Portland cement (Syarif Et AL., 2018)

\begin{tabular}{lccccccccccc}
\hline \hline Constituent & $\mathrm{SiO}_{2}$ & $\mathrm{Al}_{2} \mathrm{O}_{3}$ & $\mathrm{Fe}_{2} \mathrm{O}_{3}$ & $\mathrm{CaO}$ & $\mathrm{MgO}$ & $\mathrm{SO}_{3}$ & $\mathrm{~K}_{2} \mathrm{O}$ & $\mathrm{Na}_{2} \mathrm{O}$ & $\mathrm{Cl}$ & LOI & Compressive Strength (28-day) \\
\hline Value (\%) & 22.8 & 3.8 & 1.4 & 66.5 & 0.8 & 3.3 & 0.7 & 0.1 & $<0.1$ & 1.5 & 75.5 \\
\hline \hline
\end{tabular}

TABLE III

DETAILS OF CONCRETE MIXES

\begin{tabular}{lcccccc}
\hline \hline Series No. & W/C & Mix No. & DEPS & \multicolumn{3}{c}{ Mixture Constituents $\left(\mathrm{kg} / \mathrm{m}^{3}\right)$} \\
\cline { 5 - 7 } & & & $(\%)$ & Cement & Water & NA + DEPS \\
\hline 1 & 0.5 & 1 & $0(\mathrm{C} 1)$ & 320 & 192 & $1920+0$ \\
& & 2 & 30 & 320 & 192 & $1344+173$ \\
& & 3 & 60 & 320 & 192 & $768+345$ \\
& & 4 & 100 & 320 & 192 & $0+575$ \\
& 0.7 & 5 & $0(\mathrm{C} 2)$ & 320 & 256 & $1920+0$ \\
& & 6 & 30 & 320 & 256 & $1344+173$ \\
& & 7 & 60 & 320 & 256 & $768+345$ \\
3 & & 8 & 100 & 320 & 256 & $0+575$ \\
& 0.9 & 9 & $0(\mathrm{C} 3)$ & 320 & 320 & $1920+0$ \\
& & 10 & 30 & 320 & 320 & $1344+173$ \\
& & 11 & 60 & 320 & 320 & $768+345$ \\
& & 12 & 100 & 320 & 320 & $0+575$ \\
\hline \hline
\end{tabular}

$\mathrm{W} / \mathrm{C}$ ratios of $0.5,0.7$, and 0.9 were used for series 1 , series 2 , and series 3 , respectively. To minimize the total cost of the present study superplasticiser has not been used. Further details about the mixes are presented in Table III.

For specimens' preparation, first DEPS aggregates were wetted with $1 / 3$ of the mixing water. Then, the remaining materials were added to the mixer of $100 \mathrm{~L}$ capacity and $1 / 2$ of the remaining water was gradually added whereas the mixing was in progress. Then, the remaining $1 / 2$ of the mixing water was added and mixing was continued until a uniform concrete mix was obtained then slump measurement and casting of specimens was immediately started. After casting, specimens were covered and left undisturbed in the laboratory for $24 \mathrm{~h}$. Then, demolding took place and specimens were placed under different curing conditions for various curing times.

\section{Test Methods}

\section{Consistency and density}

The consistency or workability of the fresh concrete was measured by slump-test according to BS EN 12350-2:2009 on the mixtures of Series 1, 2, and 3, and a flow test was carried out on the mixtures in Series 3 only. Usually, the flow test is used for high workability concrete (e.g., with a slump of $175 \mathrm{~mm}$ or more). The test is carried out in accordance with BS EN 12350-5:2009. The dry density of concrete specimens which can control many physical properties in LWC and is mainly controlled by the volume and density of LWA was measured according to BS EN 12390-7:2009.

\section{Compressive strength}

For the determination of compressive strength in conformity with BS EN 12390-3:2009, cube specimens of $100 \mathrm{~mm}$ size complied with BS EN 12390-2:2012 were used. Specimens were kept under different curing conditions. Curing times were 1, 7, 28, and 365 days. A testing machine of $3000 \mathrm{kN}$ capacity at the loading rate of $0.6 \mathrm{MPa} / \mathrm{s}$ complied with BS EN 12390-4:2000 was used.

\section{Ultrasonic pulse velocity (UPV)}

For measurement of UPV values compiled with BS EN 12504-4:2004, cube specimens of $100 \mathrm{~mm}$ size were used. Curing times were 1, 7, 28, and 365 days. Specimens were kept under different curing conditions. The UPV as a nondestructive test method is used to evaluate concrete quality. This method can be used to detect internal cracking and other defects, as well as changes in concrete such as deterioration due to aggressive environment, freezing, and thawing (Yew, 2014). The pulse velocity was calculated from the formula:

$$
\mathrm{V}=\mathrm{L} / \mathrm{T}
$$

where $V$ is the pulse velocity, in $\mathrm{km} / \mathrm{s} ; L$ is the path length, in $m m ; T$ is the time taken by the pulse to transverse the $100 \mathrm{~mm}$ length, in $\mu s$.

\section{Outdoor weathering exposure}

Specimens were kept outside of the laboratory for weathering exposure effects up to 365 days age. For this type of curing, the specimens were kept outside in an open space (Fig. 2) to determine the effect of weathering on concrete properties including compressive strength and UPV. The testing ages were 7 days (September), 120 days (January), 240 days (May), and 365 days (October). At each curing time, the test was conducted at room temperature $\left(20^{\circ} \mathrm{C} \pm 2\right)$. Table IV shows the weathering details during testing.

\section{Heating exposure}

For the heating exposure curing, the specimens were cured in water for 365 days before testing. Then, the specimens were dried at $80^{\circ} \mathrm{C}$ until a constant dry mass was achieved. The specimens were heated at a heating rate of $5^{\circ} \mathrm{C} / \mathrm{min}$ up to 100,200 , and $300^{\circ} \mathrm{C}$. (It is well known that for temperatures of $110^{\circ} \mathrm{C}$ and over, the uncoated EPS beads initially may shrink and finally evaporate) (Babu and Babu, 2003). The temperature of the furnace (Fig. 3) was maintained at the target temperature for $60 \mathrm{~min}$. The furnace capacity was almost $0.2 \mathrm{~m}^{3}$ and was ventilated. The duration of exposure at elevated temperatures practically guarantees that the specimens are heated uniformly and the whole sample volume is reached with adequate accuracy (Vodák, 2004). The specimens were heated in groups of 12 . Then, the specimens were gradually cooled to the laboratory temperature. The UPV and compressive strength tests were carried out on the specimens.

\section{Results AND Discussion}

\section{A. Consistency and Density}

The consistency or workability (slump and flow table) values for concretes containing varying amounts of DEPS aggregate at different $\mathrm{W} / \mathrm{C}$ are presented in Table V. The 


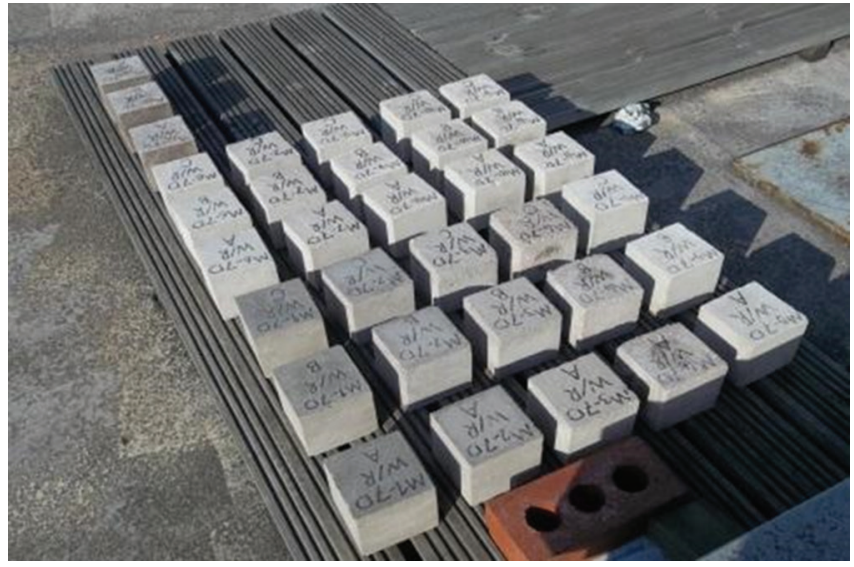

Fig. 2. Outside weathering exposure

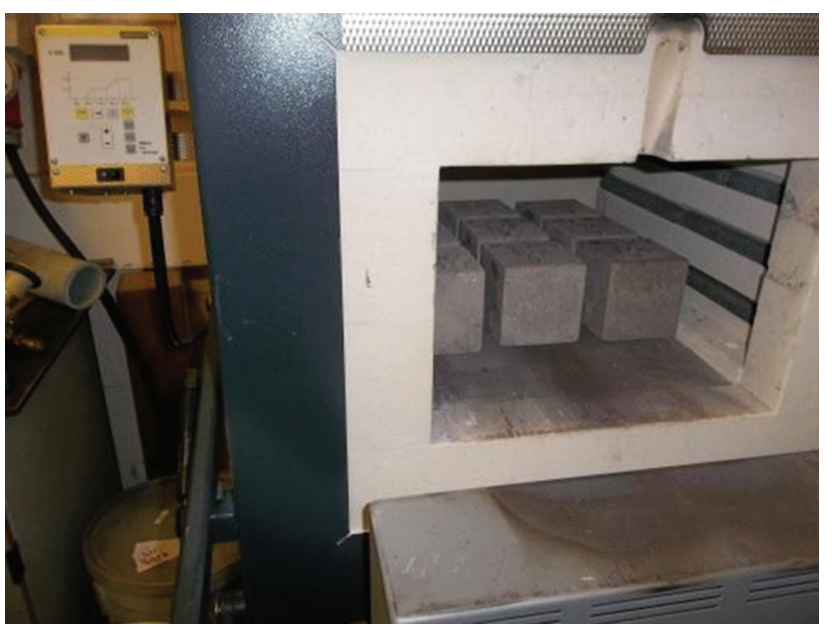

Fig. 3. Heating exposure

slump values were in the range of $3-36 \mathrm{~mm}$ in Series 2 which was typically used for foundations and in applications with light reinforcement, and $55-160 \mathrm{~mm}$ in Series 3 which these mixes are typically used for normal reinforced concrete placed with vibration and/or used in applications with tight reinforcing. None of the mixes in Series 1 recorded any slump, which means they were stiff and with appropriate mix design they can be used in some applications such as road construction. This was mainly due to the low $\mathrm{W} / \mathrm{C}$ ratio and lack of any superplasticiser which would have improved the workability (Kan and Demirboğa, 2007; Le Roy, Parant and Boulay, 2005; Ferrándiz-Mas and García-Alcocel, 2013). Flow values for Series $3(\mathrm{~W} / \mathrm{C}=0.9)$ mixes were in the range of $38-48 \mathrm{~cm}$. The workability for the mixes of the Series 1 was just enough to be compacted and could also be finished, but all other mixtures were flexible and easy to work with, and compaction and finishability were easy. The workability of the concrete increased with increasing the replacement level of DEPS aggregate in concrete up to $60 \%$ then decreased for $100 \%$ DEPS replacement. Further details about the workability are described in Table V.

The dry density of concretes containing varying amounts of DEPS aggregates is presented in Table $\mathrm{V}$. The density values were in the range of $891-2133 \mathrm{~kg} / \mathrm{m}^{3}$. According to the results reported in Table $\mathrm{V}$, the density of concretes
TABLE IV

WEATHERING DETAILS DURING TESTING

\begin{tabular}{|c|c|c|c|c|c|c|c|}
\hline \multirow[t]{3}{*}{$\overline{\text { Month }}$} & \multicolumn{4}{|c|}{ Temperature ${ }^{\circ} \mathrm{C}$} & \multicolumn{2}{|c|}{ Ave. rainfall $(\mathrm{mm})$} & \multirow[t]{3}{*}{ Ave. snow day } \\
\hline & \multicolumn{2}{|c|}{ Average } & \multicolumn{2}{|c|}{ Absolute } & \multirow[t]{2}{*}{ Daily } & \multirow[t]{2}{*}{ Monthly } & \\
\hline & Max. & Min. & Max. & Min. & & & \\
\hline January & 7.5 & 1.8 & 14 & -10 & 1.4 & 43.5 & 5 \\
\hline February & 8.1 & 1.5 & 18.1 & -10.1 & 1.3 & 37.7 & 5 \\
\hline March & 10.4 & 2.7 & 20.5 & -8 & 0.8 & 24.8 & 3 \\
\hline April & 12.7 & 3.6 & 25 & -6.4 & 1 & 31.3 & 2 \\
\hline May & 16.5 & 6.8 & 27 & -3 & 0.9 & 26.6 & 0 \\
\hline June & 19.3 & 9.7 & 31.3 & -1 & 1.2 & 35.8 & 0 \\
\hline July & 21.8 & 11.7 & 35 & 3.3 & 1.1 & 32.8 & 0 \\
\hline August & 21.6 & 11.6 & 35 & 2.9 & 0.9 & 28.6 & 0 \\
\hline September & 18.2 & 9.3 & 28 & 0.4 & 1.3 & 37.8 & 0 \\
\hline October & 13.9 & 6.5 & 23.5 & -6.8 & 1.5 & 47.6 & 0 \\
\hline November & 9.9 & 3.7 & 21 & -6 & 1.3 & 40 & 1 \\
\hline December & 7 & 1.5 & 15.2 & -13 & 1.3 & 40.2 & 4 \\
\hline
\end{tabular}

TABLE V

WORKABILITY AND DENSITY OF DEPS CONCRETES AT DIFFERENT W/C RATIOS

\begin{tabular}{lccccc}
\hline \hline Series No. & W/C & Mix No. & \multicolumn{2}{c}{ Workability } & Dry density $\left(\mathrm{kg} / \mathrm{m}^{3}\right)$ \\
\cline { 3 - 4 } & & & Slump $(\mathrm{mm})$ & Flow $(\mathrm{cm})$ & \\
\hline 1 & 0.5 & 1 & 0 & - & 2135 \\
& & 2 & 0 & - & 1965 \\
& & 3 & 0 & - & 1640 \\
2 & & 4 & 0 & - & 1020 \\
& 0.7 & 5 & 3 & - & 2075 \\
& & 6 & 20 & - & 1815 \\
& & 7 & 36 & - & 1540 \\
3 & & 8 & 15 & - & 1010 \\
& \multirow{3}{*}{0.9} & 9 & 55 & 46 & 1990 \\
& & 10 & 140 & 47 & 1740 \\
& & 11 & 160 & 48 & 1390 \\
& & 12 & 70 & 38 & 895 \\
\hline \hline
\end{tabular}

decreased with increasing the replacement level of DEPS aggregate with natural aggregates. This is because the density of DEPS aggregates was much lower than that of natural aggregates. According to BS EN 206-1:2000, the LWC must have a dry density of not less than $800 \mathrm{~kg} / \mathrm{m}^{3}$ and not more than $2000 \mathrm{~kg} / \mathrm{m}^{3}$. Thus, the concrete containing 30\% DEPS and more can be considered as LWC depending on DEPS replacement levels in concrete.

\section{B. Ultrasonic Pulse Velocity (UPV)}

\section{Effect of water curing}

This study shows an increase in DEPS in concrete leads to a decrease in UPV. This is illustrated in a comprehensive summary of UPV values of DEPS concretes for all curing conditions and series in Fig. 4. There was not a significant difference between the concrete containing 30\% DEPS and control as it is interesting to see that the reduction in UPV was only $2 \%$ in series 1 .

According to many recent investigations conducted on UPV of concrete (Yew, 2014; Demirboğa, Türkmen, and Karakoç, 2004), the UPV of concrete is classified into 4 types of "very good quality," "good to very good quality," "satisfactory," and "poor quality." Concrete made with $30 \%$ 


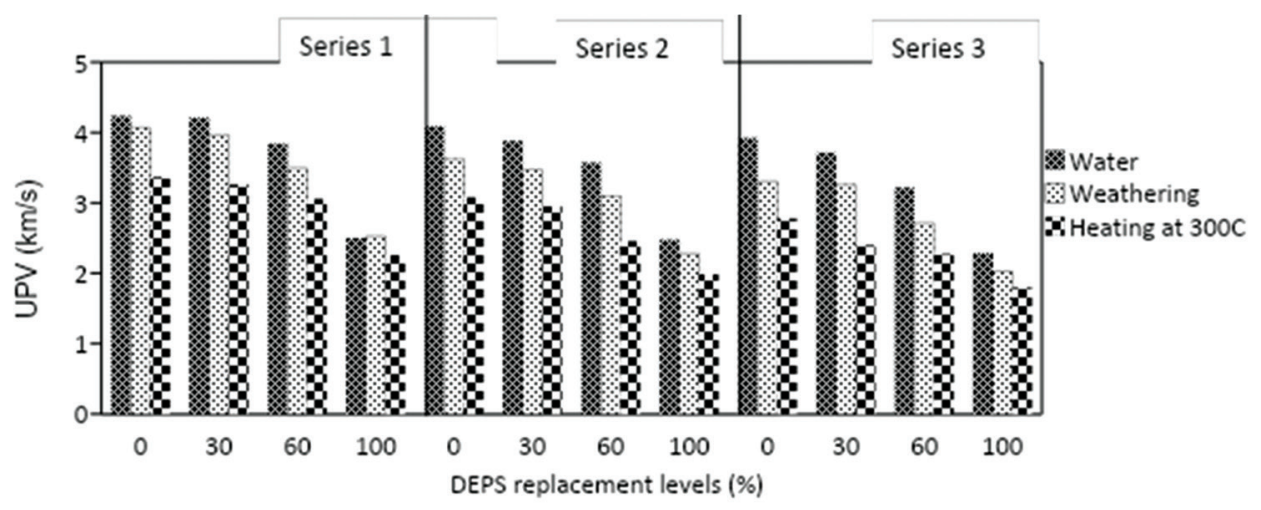

Fig. 4. Long-term study of DEPS concretes UPV values under different curing conditions

DEPS in Series 1 can comply with the Type I (very good quality) requirements. Concrete made with $60 \%$ DEPS in Series 1, and 30\% DEPS in Series 2 and 3, can comply with the Type II (good to very good quality) requirements. Concrete containing 60\% DEPS in Series 2 and 3 can comply with the Type III (satisfactory) requirements and 100\% DEPS concretes in all three series is of poor quality based on the UPV results.

The variation of the UPV values at different curing times indicates a continuous increase for all the mixes. However, there is a high rate of increase in UPV in the early ages and as curing time rises; the increase starts to slow down until it levels off asymptotically. For example, the increase in UPV value for $30 \%$ DEPS concrete from 1 to 7 day curing time was $23 \%$. This is due to the physical-chemical changes that happen in the concrete as a consequence of the hydration reactions increase progressively the strength and density of the material, favoring the propagation of the UPV as curing time increases (Albano, 2009).

The UPV values of the concretes with the same DEPS content decrease with an increase in $\mathrm{W} / \mathrm{C}$ ratio at all curing periods (Hwang, 2012; Wang, 2009). According to the recent study (36), a change in the $\mathrm{W} / \mathrm{C}$ ratio of concrete would be easily detected by UPV testing. This is due to the extra water remaining in the pores and after evaporation, leaves empty holes in the concrete structure that produces the reduction of the UPV (Albano, 2009).

\section{Effect of outdoor weather exposure}

Similar to the UPV of concrete long-term water curing, the weathering results showed that the UPV of concrete decreased as DEPS content increased. The results also showed that the UPV of concrete increased about $8 \%$ and $12 \%$ for low and high DEPS contents after 365 days of outdoor weathering exposure, respectively. The UPV of specimens continued to increase in outdoor weathering conditions due to the environment's moist and further hydration of un-hydrated or un-reacted cement particles within the specimens. Similar results have been reported elsewhere (Gunasekaran, Annadurai, and Kumar, 2012; Shi, 2012). A higher UPV shows better uniformity of the concrete. At present, in civil engineering applications, weathering studies on the degradation of concrete exposed to the environment are of great importance. Much of the knowledge on concrete deterioration comes from studies in the environment, because it is difficult to simulate the combination of conditions long-term in a laboratory. According to Amianti and Botaro (2008), microclimates can negatively affect concrete durability. They also reported that the degradation depends on the permeability, type, and geometric form of the concrete construction, as well as the type and aggressiveness of the process. Comprehensive studies into the long-term weathering performance of concrete structures exposed to severe environments for a long-term suggest that properly proportioned and placed LWC performs equal to normalweight concrete (ACI Committee 213, 2003).

It has been reported by Neville (2008) that concrete with UPV values within the range of $3.5-4.5 \mathrm{~km} / \mathrm{s}$ is considered as "Good" concrete. As long as the UPV values fall within this category, it can be deduced that the concrete does not contain any large voids or cracks which will affect its structural integrity. In the present study, the UPV values for mixes containing up to $60 \%$ DEPS at W/C of 0.5 and $30 \%$ DEPS at W/C of 0.7 fell within the above category under outdoor weathering exposure curing.

\section{Effect of heating exposure}

Measurements for UPV were carried out on the concrete samples before and after the heat treatment as explained in the methodology. A recent investigation by Biolzi, Cattaneo and Rosati (2008) reported that the UPV value, as an indicator of damage, has been used to evaluate concrete quality, as UPV is sensitive to internal cracking and other deterioration due to heating treatments. The relative properties of concrete after exposure to high temperatures during fire are of great importance in terms of the serviceability of buildings (Arioz, 2007). According to the results, in general, the UPV of concrete decreased with an increase in temperature at all DEPS percentages in all Series. The decrease in UPV with increasing temperature is a sensitive measure of the progress of cracking in the material (Savva, Manita and Sideris, 2005).

At $300^{\circ} \mathrm{C}$, the reduction in UPV of all the mixtures was between 10 and $23 \%, 20$ and $25 \%$, and 21 and $35 \%$ in series 1,2 , and 3, respectively. The mixture with $100 \%$ DEPS content recorded the lowest reduction in UPV at $300^{\circ} \mathrm{C}$ in each Series. It has been reported (Neville, 2008) that concrete with UPV values within the range of 3.5$4.5 \mathrm{~km} / \mathrm{s}$ is considered as "good" concrete as discussed 
in the last section. The UPV for the concrete containing $0 \%$ and $30 \%$ DEPS aggregate in Series 1 at $100^{\circ} \mathrm{C}$ was 3.72 and $3.69 \mathrm{~km} / \mathrm{s}$, respectively. In the present study, the UPV values for all mixes containing DEPS in all Series did not exceed $3.34 \mathrm{~km} / \mathrm{s}$ at 200 and $300^{\circ} \mathrm{C}$; however, it is well known that obtaining high UPV values for concrete containing high DEPS (EPS beads with 95\% air) are almost unexpected.

\section{Compressive Strength}

\section{Effect of indoor water curing}

A comprehensive summary of strength values of DEPS concrete under long-term water curing condition is shown in Fig. 5. The DEPS aggregates caused a reduction in the compressive strength of concrete as expected; depending on the level of replacement with natural aggregate the reduction was different. For example, at 28 days, age the reduction in compressive strength was between 1 and $73 \%, 21$ and $68 \%$, and 19 and $66 \%$ for Series 1,2, and 3, respectively, compared to the control concrete of each series. It was interesting to see that this reduction for $30 \%$ DEPS concrete in Series 1 was not significant and it was $1 \%$ only. This reduction in compressive strength is attributed to the lack of enough bonding between EPS particles and paste in the concrete incorporating unmodified EPS particles as unmodified EPS particles have almost zero strength; however, in the case of DEPS with coating (present work) it may be different (Babu and Babu, 2004). The compressive strength of the concretes containing different DEPS contents is decreased with an increase in $\mathrm{W} / \mathrm{C}$ ratio as expected. This is due to the excess of water in concrete with higher W/C causing higher porosity. Similar results have been reported elsewhere (Albano, 2009; Neville, 2008; Lo, Tang and Cui, 2007; Demirdag, Ugur and Sarac, 2008; Choi, 2005). The strength gain was different too. For example, at 7-day in Series 2 shows that concrete with $30 \%$ DEPS developed almost $63 \%$ of its 28 -day strength, while that with $100 \%$ DEPS developed almost $69 \%$ of the corresponding 28-day strength. Overall, with appropriate mix design, the utilization of DEPS in lightweight concrete production, for example, lightweight blocks and bricks are possible and adequate strength can be achieved using an appropriate curing condition and DEPS replacement level. According to Rostam, Ali and Atrushi (2016), the reduced unit weight in building material such as cellular blocks makes for ease of handling, reduced floor/foundation loading, and economic. Therefore, this mix can make it relevant to creating building blocks in Kurdistan which are lighter with moderate compressive strength that makes it suitable for better building materials.

\section{Effect of outdoor weathering exposure}

As shown in Fig. 6, due to the moist environment and further hydration of unhydrated cement particles within the samples under outdoor weathering condition, strength values are similar to those for water curing at the same age explained in the previous section; this is in agreement with the results reported by Gunasekaran, Annadurai, and Kumar, 2012; Shi, 2012; Roy, Puh and Northwood, 1999. The reduction in strength was between 2 and $75 \%, 24$ and $70 \%$, and 7 and $70 \%$ in comparison with the control concrete for Series 1, 2, and 3, respectively. Furthermore, stresses in specimens caused by weathering exposure such as freezing and thawing, wetting and drying, and heating and cooling will damage the concrete structure over time and can cause cracking in the concrete (Roy, Puh, Northwood, 2007; ACI Committee 224, 2007). ACI 224.1R (2007) recommends protecting concrete against freezing and thawing through the use of the lowest acceptable $\mathrm{W} / \mathrm{C}$ ratio, durable aggregate, and suitable air entrainment.

\section{Effect of heating exposure}

As presented in Table VI, strength values for control concrete and 30\% DEPS concrete increased and for the concrete containing 60 and 100\% DEPS decreased with an increase in heating temperature for all series (Vodák, 2004; Hossain, 2006). According to the recent published studies (Fraj, Kismi and Mounanga, 2010; Rashad, 2012; Noumowé, Siddique and Ranc, 2009; Al-Sibahy and Edwards 2012; Tanyildizi and Çevik, 2010; Mydin and Wang, 2012); generally, the level of water loss for the specimens heated

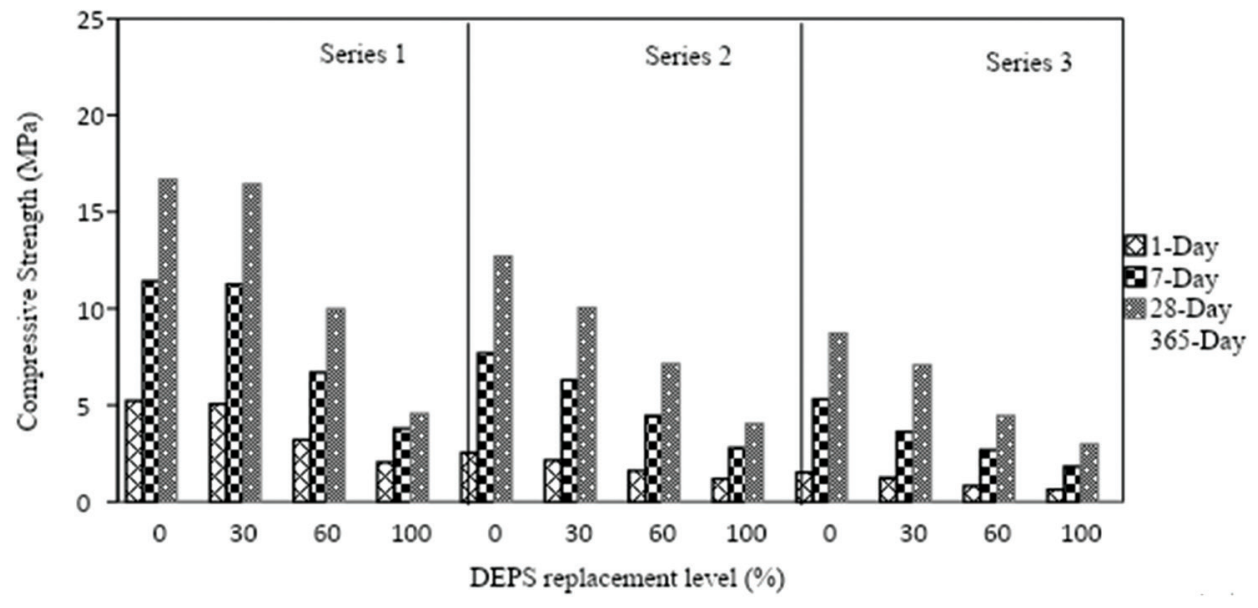

Fig. 5. Compressive strength of water cured DEPS concretes at different curing times 
TABLE VI

DEPS CONCRETES COMPRESSIVE STRENGTH AT DIFFERENT W/C RATIOS AND TEMPERATURES

\begin{tabular}{|c|c|c|c|c|c|c|}
\hline \multirow[t]{3}{*}{ Series No. } & \multirow[t]{3}{*}{$\mathrm{W} / \mathrm{C}$} & \multirow[t]{3}{*}{ Mix No. } & \multicolumn{4}{|c|}{ Compressive strength (MPa) } \\
\hline & & & \multicolumn{4}{|c|}{ Temperatures $\left({ }^{\circ} \mathrm{C}\right)$} \\
\hline & & & 20 & 100 & 200 & 300 \\
\hline \multirow[t]{4}{*}{1} & 0.5 & 1 & 25.37 & 16.53 & 26.11 & 32.43 \\
\hline & & 2 & 24.12 & 24.22 & 27.78 & 28.47 \\
\hline & & 3 & 13.02 & 13.98 & 14.76 & 13.73 \\
\hline & & 4 & 5.86 & 5.77 & 5.50 & 4.64 \\
\hline \multirow[t]{4}{*}{2} & 0.7 & 5 & 19.12 & 20.82 & 21.96 & 25.13 \\
\hline & & 6 & 14.46 & 16.52 & 16.56 & 16.46 \\
\hline & & 7 & 11.37 & 10.54 & 11.04 & 10.01 \\
\hline & & 8 & 5.15 & 5.70 & 4.94 & 4.18 \\
\hline \multirow[t]{4}{*}{3} & 0.9 & 9 & 14.31 & 14.76 & 15.23 & 16.67 \\
\hline & & 10 & 10.63 & 11.45 & 12.16 & 11.85 \\
\hline & & 11 & 7.60 & 6.93 & 6.23 & 6.49 \\
\hline & & 12 & 3.80 & 3.79 & 3.60 & 3.44 \\
\hline
\end{tabular}

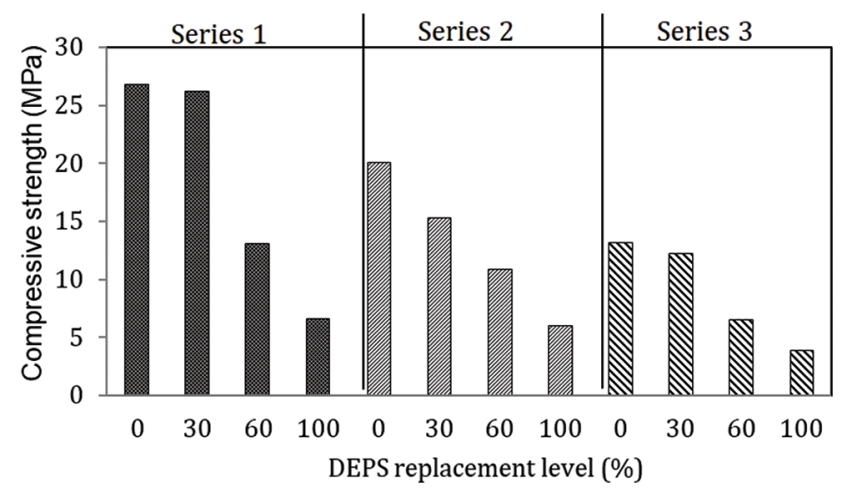

Fig. 6. Long-term study of DEPS concretes compressive strength under outdoor weathering exposure

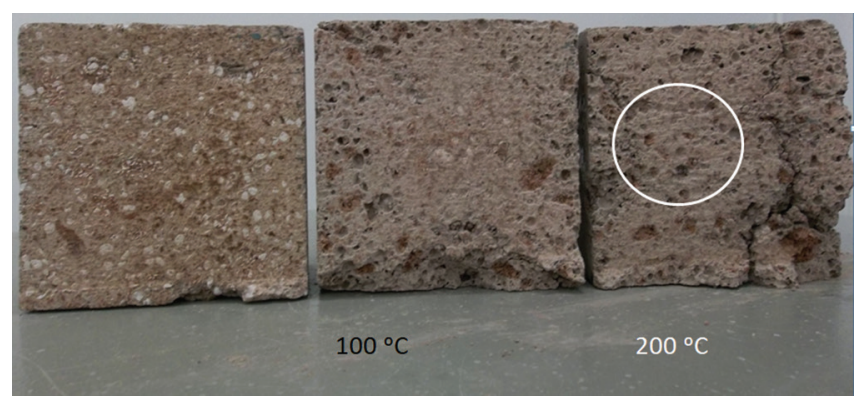

Fig. 7. Effect of different temperatures on 100\% DEPS concrete

at 200 and $300^{\circ} \mathrm{C}$ was much higher than that measured on the specimens heated at $100^{\circ} \mathrm{C}$ as expected; this is confirmed that there is a small proportion of extra water in the concrete compared to the water needed for hydration.

According to the results, except for control concrete in Series 1 there was no significant difference in compressive strength obtained between 20 (lab temperature) and $100^{\circ} \mathrm{C}$ heating exposure. At $200^{\circ} \mathrm{C}$, the EPS particles of DEPS aggregate in concrete started to evaporate as shown by the small holes which can be seen on the cross-section of specimens with $100 \%$ DEPS (Fig. 7) which resulted in increased porosity. The damage at $200^{\circ} \mathrm{C}$ in the center of the specimen was less but the damages at $300^{\circ} \mathrm{C}$ on the specimen were higher, as expected, which can be seen in Fig. 7 in the form of cracks. At high temperatures the interfacial transition zone between cement paste and aggregate will be weakened and strength and durability properties can be decreased (Hossain, 2006). The authors recommend that to reduce water loss at high temperatures concrete containing DEPS should be protected by a fire protection material as a coating layer.

\section{CONCLUSIONS}

The main aim of this investigation was to study the longterm effect of different curing conditions on engineering properties of concrete incorporating a novel LWA called DEPS. The experimental study results provided the following conclusions:

- In general, the concrete containing DEPS can be used in low-strength concrete applications for example to produce lightweight bricks and blocks with low thermal conductivity. However, with appropriate mix design, the utilization of DEPS in lightweight concrete production is possible and adequate strength can be achieved using an appropriate curing condition and DEPS replacement level;

- The consistency of concrete increased with an increase in DEPS content up to $60 \%$; beyond $60 \%$ the consistency started to decrease also the density of the concretes decreased with an increase in DEPS aggregate replacement;

- Due to the availability of water for better hydration, the UPV values of the concretes made with different DEPS percentages under water curing was higher than that of outdoor weather and heating exposure conditions;

- The compressive strength values of concrete under outdoor curing conditions were similar to that of water curing. However, the heating curing condition had a great influence on the compressive strength. The compressive strength of the control and 30\% DEPS concrete increased, and of the concrete containing 60 and $100 \%$ DEPS aggregate decreased, with an increase in heating temperature; thus, a fire protection coating layer is recommended.

- For production of cellular blocks in the Kurdistan Region the use of DEPS in the concrete mix could be a good alternative and therefore it should be examined further.

\section{REFERENCES}

Abbasi, S., Jannaty, M.H., Faraj, R.H., Shahbazpanahi, S., and Mosavi, A., 2020. The effect of incorporating silica stone waste on the mechanical properties of sustainable concretes. Materials, 13, p.3832.

ACI Committee 213, 2003. Guide for Structural Lightweight Aggregate Concrete. American Concrete Institute Manual of Concrete Practice, United Kingdom.

ACI Committee 224, 2007. Causes, Evaluation and Repair of Cracks in Concrete Structures (ACI 224.1R-07), Manual of Concrete Practice, Part 2. American Concrete Institute, Farmington Hills.

Albano, C., Camacho, N., Hernández, M., Matheus, A., and Gutiérrez, A., 2009. Influence of content and particle size of waste pet bottles on concrete behaviour at different w/c ratios. Waste Management, 29(10), pp.2707-2716. 
Al-Sibahy, A., and Edwards, R., 2012. Thermal behaviour of novel lightweight concrete at ambient and elevated temperatures: Experimental, modelling and parametric studies. Construction and Building Materials, 31, pp.174-187.

Amianti, M., and Botaro, V.R., 2008. Recycling of EPS: A new methodology for production of concrete impregnated with polystyrene (CIP). Cement and Concrete Composites, 30(1), pp.23-28.

Arioz, O., 2007. Effects of elevated temperatures on properties of concrete. Fire Safety Journal, 42(8), pp.516-522.

Babu, D.G., Babu, K.G., and Wee, T.H., 2005. Properties of lightweight expanded polystyrene aggregate concretes containing fly ash. Cement and Concrete Research, 35(6), pp.1218-1223.

Babu, D.S., Ganesh Babu, K., and Tiong-Huan, W., 2006. Effect of polystyrene aggregate size on strength and moisture migration characteristics of lightweight concrete. Cement and Concrete Composites, 28(6), pp.520-527.

Babu, K.G., and Babu, D.S., 2003. Behaviour of lightweight expanded polystyrene concrete containing silica fume. Cement and Concrete Research, 33(5), pp.755-762.

Babu, K.G., and Babu, D.S., 2004. Performance of fly ash concretes containing lightweight EPS aggregates. Cement and Concrete Composites, 26(6), pp.605611.

Biolzi, L., Cattaneo, S., and Rosati, G., 2008. Evaluating residual properties of thermally damaged concrete, Cement and Concrete Composites, 30(10), pp.907-916.

Bouvard, D., Chaix, J.M., Dendievel, R., Fazekas, A., Létang, J.M., Peix, G., and Quenard, D., 2007. Characterization and simulation of microstructure and properties of EPS lightweight concrete. Cement and Concrete Research, 37(12), pp.1666-1673.

British Standards Institution, BS EN 12350-2:2009, 2009. Testing Fresh Concrete Part 2: Slump-test. British Standards Institution, United Kingdom.

British Standards Institution, BS EN 12350-5:2009, 2009. Testing Fresh Concrete Part 5: Flow Table Test. British Standards Institution, United Kingdom.

British Standards Institution, BS EN 12390-2:2012, 2012. Testing Hardened Concrete Part 2: Making and Curing Specimens for Strength Tests. British Standards Institution, United Kingdom.

British Standards Institution, BS EN 12390-3:2009, 2009. Testing Hardened Concrete Part 3: Compressive Strength of Test Specimens. British Standards Institution, United Kingdom.

British Standards Institution, BS EN 12390-4:2000, 2000. Testing Hardened Concrete Part 4: Compressive Strength, Specification for Testing Machines. British Standards Institution, United Kingdom.

British Standards Institution, BS EN 12390-7:2009, 2009. Testing Hardened Concrete Part 7: Density of Hardened Concrete. British Standards Institution, United Kingdom.

British Standards Institution, BS EN 12504-4:2004, 2004. Testing Concrete Part 4: Determination of Ultrasonic Pulse Velocity. British Standards Institution, United Kingdom.

British Standards Institution, BS EN 206-1:2000, 2000. Concrete Part 1: Specification, Performance, Production and Conformity. British Standards Institution, United Kingdom.

British Standards Institution, BS EN 933-1:1997, 1997. Tests for Geometrical Properties of Aggregates. Part 1: Determination of Particle Size Distributionsieving Method. British Standards Institution, United Kingdom.

Chen, B., and Liu, J., 2004. Properties of lightweight expanded polystyrene concrete reinforced with steel fiber. Cement and Concrete Research, 34(7), pp.1259-1263.

Chen, B., and Liu, J., 2007. Mechanical properties of polymer-modified concretes containing expanded polystyrene beads. Construction and Building Materials, 21(1), pp.7-11.
Choi, Y.W., Moon, D.J., Chung, J.S., and Cho, S.K., 2005. Effects of waste PET bottles aggregate on the properties of concrete. Cement and Concrete Research, 35(4), pp.776-781.

Demirboğa, R., Türkmen, I., and Karakoç, M.B., 2004. Relationship between ultrasonic velocity and compressive strength for high-volume mineral-admixtures concrete. Cement and Concrete Research, 34(12), pp.2329-2336.

Demirdag, S., Ugur, I., and Sarac, S., 2008. The effects of cement/fly ash ratios on the volcanic slag aggregate lightweight concrete masonry units. Construction and Building Materials, 22(8), pp.1730-1735.

Ferrándiz-Mas, V., and García-Alcocel, E., 2013. Durability of expanded polystyrene mortars. Construction and Building Materials, 46, pp.175-182.

Fraj, A.B., Kismi, M., and Mounanga, P., 2010. Valorisation of coarse rigid polyurethane foam waste in lightweight aggregate concrete. Construction and Building Materials, 24(6), pp.1069-1077.

Gunasekaran, K., Annadurai, R., and Kumar, P.S., 2012. Long term study on compressive and bond strength of coconut shell aggregate concrete. Construction and Building Materials, 28(1), pp.208-215.

Herki, B.A., 2017. Absorption characteristics of lightweight concrete containing densified polystyrene. Civil Engineering Journal, 8(3), pp.594-609.

Herki, B.A., and Khatib, J.M., 2016. Valorisation of waste expanded polystyrene in concrete using a novel recycling technique. European Journal of Environmental and Civil Engineering, 21, pp.1-19.

Herki, B.A., Khatib, J.M., and Negim, E.M., 2013. Lightweight concrete made from waste polystyrene and fly ash. World Applied Science Journal, 21, pp.1356-1360.

Hossain, K.M.A., 2006. High strength blended cement concrete incorporating volcanic ash: Performance at high temperatures. Cement and Concrete Composites, 28(6), pp.535-545.

Hwang, C.L., Bui, L.A.T., Lin, K.L., and Lo, C.T., 2012. Manufacture and performance of lightweight aggregate from municipal solid waste incinerator fly ash and reservoir sediment for self-consolidating lightweight concrete. Cement and Concrete Composites, 34(10), pp.1159-1166.

Kan, A., and Demirboğa, R., 2007. Effect of cement and EPS beads ratios on compressive strength and density of lightweight concrete. Indian Journal of Engineering and Materials Sciences, 14, pp.158-162.

Kan, A., and Demirboğa, R., 2009. A novel material for lightweight concrete production. Cement and Concrete Composites, 31(7), pp.489-495.

Khatib, J.M., Herki, B.A., and Elkordi, A., 2019. Use of Recycled Plastics in Eco-efficient Concrete, Characteristics of Concrete Containing EPS. Woodhead Publishing, United Kingdom, pp.137-165.

Khatib, J.M., Herki, B.A., and Kenai, S., 2013. Capillarity of concrete incorporating waste foundry sand. Construction and Building Materials, 47, pp.867-871.

Laukaitis, A., Žurauskas, R., and Kerien, J., 2005. The effect of foam polystyrene granules on cement composite properties. Cement and Concrete Composites, 27(1), pp.41-47.

Le Roy, R., Parant, E., and Boulay, C., 2005. Taking into account the inclusions' size in lightweight concrete compressive strength prediction. Cement and Concrete Research, 35(4), pp.770-775.

Lo, T.Y., Tang, W.C., and Cui, H.Z., 2007. The effects of aggregate properties on lightweight concrete. Building and Environment, 42(8), pp.3025-3029.

Miled, K., Le Roy, R., Sab, K., and Boulay, C., 2004. Compressive behaviour of an idealized EPS lightweight concrete: Size effects and failure mode. Mechanics of Materials, 36(11), pp.1031-1046.

Mydin, M.A.O., and Wang, Y.C., 2012. Mechanical properties of foamed concrete exposed to high temperatures. Construction and Building Materials, 26(1), pp.638-654. 
Neville, A.M., 2008. Properties of Concrete. $4^{\text {th }}$ ed. Pearson Education Limited, Essex, UK.

Nikbin, I.M., and Golshekan, M., 2018. The effect of expanded polystyrene synthetic particles on the fracture parameters, brittleness and mechanical properties of concrete. Construction and Building Materials, 94, pp.160e-172.

Noumowé, A., Siddique, R., and Ranc, G., 2009. Thermo-mechanical characteristics of concrete at elevated temperatures up to $310^{\circ} \mathrm{C}$. Nuclear Engineering and Design, 239(3), pp.470-476.

Park, S.G., and Chisholm, D.H., 1999. Polystyrene aggregate concrete. Building Research Association of New Zealand, Study Report, SR 85, Judgeford.

Rashad, A.M., Bai, Y., Basheer, P.A.M., Collier, N.C., and Milestone, N.B., 2012. Chemical and mechanical stability of sodium sulphate activated slag after exposure to elevated temperature. Cement and Concrete Research, 42(2), pp.333-343.

Ravindrarajah S.R., Camporeale M.J., and Caraballo C.C., 1996. Flexural Creep of Ferro Cement. In: Polystyrene Concrete Composite. Second International Conference on Advances in Composites, Bangalore, India.

Rostam, D., Ali, T., and Atrushi, S.D., 2016. Economical and structural feasibility of concrete cellular and solid blocks in Kurdistan region. ARO, The Scientific Journal of Koya University, 4(1), pp.1-7.

Roy, S., Puh, K.B., and Northwood, D.O., 1999. Durability of concreteaccelerated carbonation and weathering studies. Building and Environment, 34(5), pp.597-606.

Sabaa, B., and Ravindrarajah, R.S., 1997. Engineering Properties of Lightweight Concrete Containing Crushed Expanded Polystyrene Waste. Symposium MM, Advances in Materials for Cementitious Composites, United States, pp.1-11.
Sadrmomtazi, A., Sobhani, J., Mirgozar, M.A., and Najimi, M., 2012. Properties of multi-strength grade eps concrete containing silica fume and rice husk ash. Construction and Building Materials, 35, pp.211e-219.

Savva, A., Manita, P., and Sideris, K., 2005. Influence of elevated temperatures on the mechanical properties of blended cement concretes prepared with limestone and siliceous aggregates. Cement and Concrete Composites, 27(2), pp.239-248.

Shi, C., Wang, D., He, F., and Liu, M., 2012. Weathering properties of $\mathrm{CO}_{2}$-cured concrete blocks, resources. Conservation and Recycling, 65, pp.11-17.

Syarif, M., Sampebulu, V., Tjaronge, M.W., and Nasruddin. 2018. Characteristics of compressive and tensile strength using the organic cement compare with Portland cement. Case Studies in Construction Materials, 9, p.e00172.

Tang, W.C., Lo, Y., and Nadeem, A., 2008. Mechanical and drying shrinkage properties of structural-graded polystyrene aggregate concrete. Cement and Concrete Composites, 30(5), pp.403-409.

Tanyildizi, H., and Çevik, A., 2010. Modelling mechanical performance of lightweight concrete containing silica fume exposed to high temperature using genetic programming. Construction and Building Materials, 24(12), pp.26122618.

Vodák, F., Trtík, K., Kapičková, O., Hošková, Š., and Demo, P., 2004. The effect of temperature on strength-porosity relationship for concrete. Construction and Building Materials, 18(7), pp.529-534.

Wang, H.Y., 2009. Durability of self-consolidating lightweight aggregate concrete using dredged silt. Construction and Building Materials, 23(6), pp.2332-2337.

Yew, M.K., Mahmud, H.B., Ang, B.C., and Yew, M.C., 2014. Effects of heat treatment on oil palm shell coarse aggregates for high strength lightweight concrete. Materials and Design, 54, pp.702-707. 